\title{
Effectiveness of Virgin Coconut Oil in The Provision of Injury Pressure Sores Stroke Patients: Systematic Review
}

\author{
Nurul Indah Sya'bani, Muh. Anwar Hafid, A. Budiyanto Adi Putra \\ UIN Alauddin Makassar, Indonesia \\ Coresponding author: nurulsyabani2027@gmail.com
}

\begin{abstract}
Background: VCO is an oil made from fresh coconuts and processed naturally or do not require heating and do not add other chemicals. The fatty acids contained in the VCO has the added benefit of making your skin soft. VCO is effectively applied as a moisturizer to the skin so that it can improve skin hydration and promotes healing of the skin. Decubitus is damage to the skin caused by friction or pressure on the skin located bony section.

Purpose: This literature review aimed to determine the effectiveness of the VCO in reducing the risk of decubitus sores

Method: This research method Quantitative descriptive approach Systematic Review through some journals that are relevant to this article. This research article search by using keywords 1 "prevention of decubitus sores" keyword 2 "VCO" search database sources used in this study is Portal Garuda, ISJD and Google Scholar were published from 2015 to 2019 year.

Results: The results of this study identified include the use of VCO prevent decubitus sores, that VCO is effective in prevention of decubitus sores in patients with stroke or bedrest.The use of VCO as decubitus sores preventive therapy has many benefits. Substances that are contained in the VCO can provide benefits or nutrients to keep the skin moist.

Conclusion: Nurses as nursing care providers are expected to use the VCO to prevent decubitus sores in patients with stroke or bedrest as an intervention in a hospital or as therapy can do at home community.
\end{abstract}

Keywords: Wound Pressure sores, Patient Stroke, Virgin Coconut Oil (VCO) 


\section{BACKGROUND}

Decubitus is damage to the skin caused by friction or pressure on the skin located bony section (NPUAP, 2014). The inability to move actively so that the pressure and friction on the skin surface that stands out, the pressure on the skin can cause ischemia and hypoxemia due to reduced blood flow (McCance, 2018).

Stroke is a disease of the brain nerve dysfunction locally or globally, the rise of a sudden, progressive, and fast (Mendis, 2015). Strokes can occur due to the blood and oxygen should be delivered to brain disorders such as obstruction or rupture of blood vessels, where deliver blood vessels these components resulting in less oxygen in the brain affects the body movement that controlled the brain is not functioning (Mozaffarian, 2016).

Mendis (2015), states that stroke is the second sequence of the deadly disease after heart disease. A stroke more triggered by hypertension, diabetes mellitus, obesity and various disorders of blood flow to the brain. The incidence of stroke the world as much as $37 \%$ of the 58.5 million people 17.7 million people worldwide died.

Judging from the results Riskesdas 2018, in Indonesia the incidence of stroke increases with age. Obtained the number of stroke patients in 2018 at the age of 55-64 years $(32.4 \%)$, aged $65-74$ years $(45.3 \%)$ and the highest at the age of 75 years and older $(50.2 \%)$.

The prevalence of stroke cases in Indonesia is based on a diagnosis of health personnel by 10.9 per mill. The prevalence of stroke cases is highest in East Kalimantan province $(14.7 \%)$ and the lowest in the province of Papua $(4.1 \%)$. The prevalence of stroke male $(11.0 \%)$ and women $(10.9 \%)$. While the prevalence in South Sulawesi region amounted to $(9.8 \%)$ (Riskesdas, 2018).

WHO survey conducted on 55 hospitals in 14 countries showed $8.7 \%$ of the hospital there are patients with decubitus sores. The incidence of decubitus sores in stroke patients based on research Walker (2017) of 265 stroke patients, as many as 56 people (21\%) had pressure sores. In Indonesia alone, the number of incidence of pressure sores are quite high in Asia, where the incidence of pressure sores ranging from 2.1 to $31.3 \%$. Based on the results of research conducted by Said (2018), in hospitals Labuang Makassar Baji states that $32.3 \%$ of patients experienced decubitus sores.

Virgin Coconut Oil (VCO) is yielding coconut oil processed naturally or do not require heating and do not add other chemicals to produce oil with a clear color. Fatty acids contained (especially soluble acid and oleic) in VCO effectively applied as a moisturizer to the skin so that it can improve skin hydration and accelerate healing of the skin. (Kappally, 2015).

Nursing theory is applied as an approach to the theory of Dorothy Orem, said that self-care is a conceptual model to improve the ability of the patient or the family in caring for themselves and care for his family independently and used as a basis independence nurses to patients or their families according to their ability or level of dependency. Therefore, to be able to meet the objectives of the theory according to Orem, namely, the ability of nurses to help clients meet the needs and provide partial self-care, such as nurses to help stroke patients in the mobilization and intervention prevention of decubitus sores.

Decubitus sores would interfere with the recovery process of patients, and also followed with pain and infectious complications that add to the long duration of treatment. Many of intervention or therapy in the prevention of decubitus sores on pasie stroke or other bedrest. So it takes the value of the effectiveness of the treatment will be given. This 


\section{Journal Of Nursing Practice}

http://thejnp.org

ISSN: 2614-3488 (print); 2614-3496 (online)

Vol.3 No.2. April 2020. Page.181-187

literature review aimed to determine the effectiveness of the VCO in reducing the risk of decubitus sores.

\section{OBJECTIVE}

This literature review aimed to determine the effectiveness of the VCO in reducing the risk of decubitus sores.

\section{METHODS}

The design of this research is descriptive quantitative systematic review approach. This study uses a systematic review approach to find an effective intervention strategies in the provision of virgin coconut oil to prevent decubitus sores in stroke patients.This research article search strategy using the keyword 1 "prevention of decubitus sores" keyword 2 " virgin coconut oil"sumber search database used in this study is Portal eagle, Google Schoolar and ISJD.

The inclusion and exclusion criteria in this study are the criteria for inclusion: articles that terpublish in 2015-2019; articles fullteks articles that match the topics and there ISSN; journal VCO intervention as preventive therapy decubitus sores, exclusion criteria: interventions that require a lot of tools and materials.

After collecting data and information, all of the data and the relevance of such information selected by using Duffy's Research Appraisal Checklist Approachwith the considered problem. To present the issues to be discussed, the data collected was analyzed descriptively.

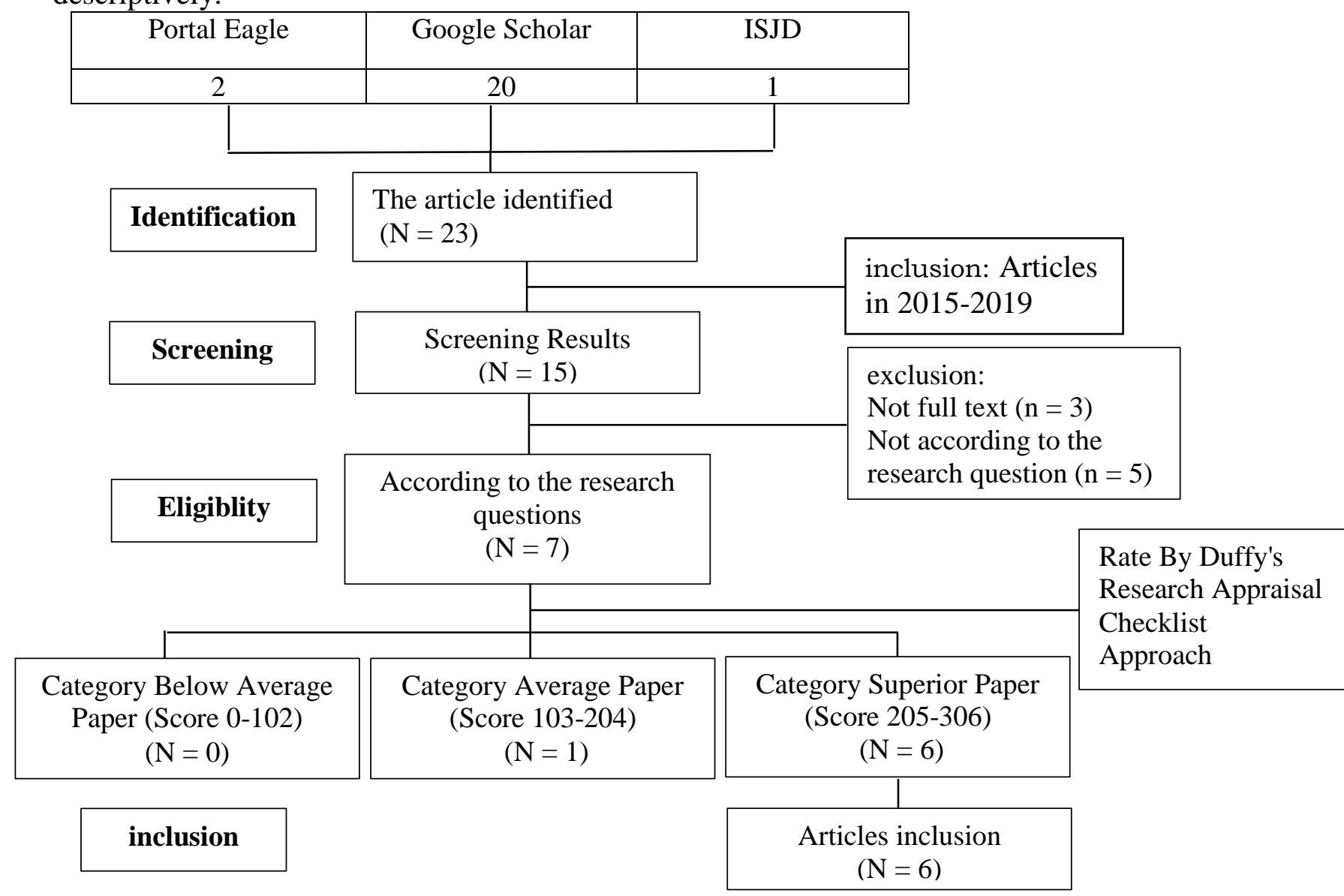

Figure 1. A flow diagram for selection and inclusion studies 


\section{Journal Of Nursing Practice}

http://thejnp.org

ISSN: 2614-3488 (print); 2614-3496 (online)

Vol.3 No.2. April 2020. Page.181-187

\section{RESULTS}

A total of 23 articles were identified from all three search literature data after the selection (years 2015 to 2019, the research only in humans and are associated with a research question). Authors assess all articles identified independently for inclusion in the systematic review. Of the 23 articles that have the potential, there are three exclusion because it is not a full text, 5 were excluded because it does not suit the purpose of research. Studies diinklusi for this literature review should be (1) a focus on intervention VCO preventive therapy of decubitus sores, (2) fullteks articles according to the topic and there ISSN and (3) published from 2015 to 2019.

From 7 articles were taken, one article was excluded because it is an average of paper (a score of 103-204) based on an assessment by Duffy's Research Appraisal Checklist Approach. Thus, only 6 articles that met the inclusion criteria with articles intervention. Figure 2 illustrates the process of inclusion of the study. The article was included and criticized using assessment tools to Duffy's Research Appraisal Checklist Approach.

\section{DISCUSSION}

Decubitus is damage to the skin caused by friction or pressure on the skin located bony section (NPUAP, 2014). The inability to move actively so that the pressure and friction on the skin surface that stands out, the pressure on the skin can cause ischemia and hypoxemia due to reduced blood flow (McCance, 2018).

VCO is yielding coconut oil processed naturally or do not require heating and do not add other chemicals to produce oil with a clear color. Fatty acids contained (especially soluble acid and oleic) in VCO effectively applied as a moisturizer to the skin so that it can improve skin hydration and support healing of the skin. (Kappally, 2015).

The first journal written by Sihombing (2014) shows the results of the study found a back massage using VCO can prevent decubitus sores by $80 \%$ in patients who have significant risk $(\mathrm{P}<0.05)$. White back massage using petroleum jelly can prevent decubitus sores by $68 \%$ in patients at risk were significantly $(\mathrm{p}<0.05)$. It can be seen that the administration of the VCO has a higher effectiveness compared to white petroleum jelly. Giving VCO in patients with stroke or bed rest can be recommended as a treatment to prevent decubitus sores.

In line with the research results Dewandono (2014), states that a massage with VCO can be done as a nursing intervention to prevent injury dekbutis in patients who have a risk of injury decubitus, according to the nursing models by Orem, where the main focus of the conceptual model self-care is increasing a person or family's ability to care for themselves or their family members independently in order to reach the ability to sustain the health and well-being.

The second journal written by Wasliyah (2018), shows the results of research that administration of VCO and olive oil are equally effective in the prevention of decubitus sores. Based on the results Handayani (2010) shows the results of research that between administration without giving $\mathrm{VCO}$ and $\mathrm{VCO}$ against decubitus sores have significant differences.

The third journal written by Fatonah (2016), with the title. VCO awarding research shows more effective for lowering scale compared decubitus wound with ordinary coconut oil. Nevin (2010), conducted research to identify the effect of topical skin and VCO to component amtioksidan status during dermal wound and found that wounds treated with VCO cured more quickly. 


\section{Journal Of Nursing Practice}

http://thejnp.org

ISSN: 2614-3488 (print); 2614-3496 (online)

Vol.3 No.2. April 2020. Page.181-187

According to Dhikhil (2014), some of the health benefits contained in the VCO is: Reduce inflammation; support in the repair and healing of tissue, killing the bacteria that cause ulcers, throat infections, urinary tract infections, gum disease and oral cavity, pneumonia and help the immune system function.

The fourth journal written by Setyawati (2015), shows the results of research that does mobilization intervention every two smpai 3 hours by giving VCO against decubitus sores equally has an efficiency The also no difference. Results of previous studies regarding the risk of decubitus sores in patients bedrest stated that the VCO can reduce the risk of decubitus wound on a patient bed rest (Dhikhil, 2014).

The fifth journal written by Lertwattanaruk (2015), show study results showed that their efficiency The VCO in the provision in the prevention of decubitus sores which do experiments in the intervention group was given the $\mathrm{VCO}$ while the control group without the VCO. According to the Institute for Clinical Systems (ICSI), reveals one decubitus sores prevention is to reduce or eliminate friction and pressure. Periodically, use hypoallergenic lubricating oils, creams or lotions that can reduce pressure and friction. Virgin coconut oil can be used as a topical prevention of decubitus sores because the content varied.

Journal of the sixth written by Setiani (2017), shows the results of the study that administration of VCO as a medium for massage on the prevention of injuries decubitus produce efficiency The good which is done on two groups, namely a group of interventions that massage with VCO and a control group that is SOP care in preventing injuries decubitus.

The main cause of the stroke is happening motor deficits such as hemiplegia hemiparase and thus experience a state of mobility. This situation can cause a decline in general limb muscle strength, decreased flexibility and strength of joints that can lead to contractures and ultimately the patient will be experiencing limitations to perform activities. Due to a decrease in muscle strength in patients with stroke will usually impaired mobility or the ability to move the body and normal free thus have an increased risk for pressure sores during treatment.

Patients must be hospitalized and impaired mobility will occur the onset of pressure sores, because of pressure on the body. So patients with prolonged immobilization great potential to experience pressure sores (Widodo, 2017).

Thus the VCO is pure coconut oil has many benefits is very easy to get out of a wide range of products that are in Indonesia and this VCO though we can also create your own or where the materials and tools make it easy to obtain VCO.

\section{CONCLUSION}

Based on 23 articles were obtained from several databases that portals eagle, google scholar and ISJD, then checked back in inclusion and exclusion criteria, there are 7 articles. After the assessmentby Duffy's Research Appraisal Checklist Approach showed 6 articles. There are 6 article is about the effectiveness of virgin coconut oil (VCO) in decubitus sores stroke patients, that intervention on patients with stroke VCO administration effective for use in preventing the risk of decubitus sores. The results of the six articles indicate that some journals do research with quasi experiment research design to injured patients at risk of pressure sores and administration of the VCO to prevent the decubitus sores. Systematic Review of the results, it can be concluded that some journals Award VCO) of patients with stroke above show significant effectiveness and therapy given to prevent the risk of decubitus sores. 


\section{Journal Of Nursing Practice}

http://thejnp.org

ISSN: 2614-3488 (print); 2614-3496 (online)

Vol.3 No.2. April 2020. Page.181-187

\section{REFERENCES}

Dewandono, I. D. (2014). Pemanfaatan Vco (Virgin Coconut Oil) Dengan Teknik Massage Dalam Penyembuhan Luka Dekubitus Derajat II Pada Lansia. Stikes Kusuma Husada Surakarta. 1-17.

Dhikhil, C. D., Lubna, K. M., \& Scholar, L. E. V. (2014). Effect of coconut oil usage in risk of pressure ulcers among bedridden patients of selected hospitals in North India. IP-Planet, 1(2), 71-8.

Fatonah, S., Hrp, A. K., \& Dewi, R. (2016). Efektifitas Penggunaan Virgin Coconut Oil (Vco) Secara Topikal Untuk Mengatasi Luka Tekan (Dekubitus) Grade I Dan II. Jurnal kesehatan, 4(1). http://dx.doi.org/10.26630/jk.v4i1.10

Handayani, R. S. (2010). The Effective of virgin coconut oil (VCO) with massage to Prevent Pressure Ulcer Grade I incident in patient with risk of pressure ulcer at Dr. Hi. Abdul Moeloek Hospital, Lampung Province. Thesis. Universitas Indonesia.

Kappally, S., Shirwaikar, A., \& Shirwaikar, A. (2015). Coconut oil-a review of potential applications. Hygeia Journal of Drugs and Medicine, 7(2), 34-41.

Lertwattanaruk, P., \& Suntijitto, A. (2015). Properties of natural fiber cement materials containing coconut coir and oil palm fibers for residential building applications. Construction and Building Materials, 94, 664-669. https://doi.org/10.1016/j.conbuildmat.2015.07.154

McCance, K. L., \& Huether, S. E. (2018). Pathophysiology-E-book: the biologic basis for disease in adults and children. Elsevier Health Sciences.

Mendis, S., Davis, S., \& Norrving, B. (2015). Organizational update: the world health organization global status report on noncommunicable diseases 2014; one more landmark step in the combat against stroke and vascular disease. Stroke, 46(5), e121-e122. https://doi.org/10.1161/STROKEAHA.115.008097

Mozaffarian, D., Benjamin, E. J., Go, A. S., Arnett, D. K., Blaha, M. J., Cushman, M., ... \& Howard, V. J. (2016). Executive summary: heart disease and stroke statistics2016 update: a report from the American Heart Association. Circulation, 133(4), 447-454. https://doi.org/10.1161/CIR.0000000000000366

National Pressure Ulcer Advisory Panel (US), \& Haesler, E. (2014). Prevention and treatment of pressure ulcers: quick reference guide. Cambridge Media.

Nevin, K. G., \& Rajamohan, T. (2010). Effect of topical application of virgin coconut oil on skin components and antioxidant status during dermal wound healing in young rats. Skin Pharmacology and Physiology, 23(6), 290-297. https://doi.org/10.1159/000313516

RISKESDAS. (2018). Laporan Nasional Riskesdas 2018. Jakarta: Indonesian Ministry of Health Research and Development.

Said, S., Haskas, Y., \& Semana, A. (2013). FAKTOR YANG MEMPENGARUHI TERJADINYA DEKUBITUS PADA PASIEN YANG DIRAWAT DI RUANG ICU RS LABUANG BAJI MAKASSAR. Jurnal Ilmiah Kesehatan Diagnosis, 2(1), 7-12.

Setiani, D. (2017). Efektivitas Massage Dengan Virgin Coconut Oil Terhadap Pencegahan Luka Tekan Di Intensive Care Unit. Husada Mahakam: Jurnal Kesehatan, 3(8), 395-406. 


\section{Journal Of Nursing Practice}

http://thejnp.org

ISSN: 2614-3488 (print); 2614-3496 (online)

Vol.3 No.2. April 2020. Page.181-187

Setyawati, R., \& Noor, M. A. (2015). PENGARUH MOBILISASI DAN PENGGUNAAN VCO (VIRGIN COCONUT OIL) TERHADAP ULKUS DEKUBITUS PADA GANGGUAN FUNGSI MOTORIK PASCA STROKE. Nurscope: Jurnal Penelitian dan Pemikiran Ilmiah Keperawatan, 1(2), 1-6. http://dx.doi.org/10.30659/nurscope.1.2.1-6

Sihombing, N. T., Silalahi, J., \& Suryanto, D. (2014). Antibacterial activity of aqueous garlic (Allium sativum) extracts and virgin coconut oil and their combination against Bacillus cereus ATCC 14579 and Escherichia coli ATCC 8939. Int J Chemtech Res, 6, 2774-2782.

Thorson, D., Biewen, P., \& Bonte, B. (2014). Institute for Clinical Systems Improvement. Acute Pain Assessment and Opioid Prescribing Protocol.

Walker, M. F., Hoffmann, T. C., Brady, M. C., Dean, C. M., Eng, J. J., Farrin, A. J., ... \& Radford, K. A. (2017). Improving the development, monitoring and reporting of stroke rehabilitation research: Consensus-based core recommendations from the Stroke Recovery and Rehabilitation Roundtable. International Journal of Stroke, 12(5), 472-479. https://doi.org/10.1177\%2F1747493017711815

Wasliyah, S. (2018). EFEKTIVITAS PENGGUNAAN VIRGIN COCONUT OIL (VCO) DAN MINYAK ZAITUN UNTUK PENCEGAHAN LUKA TEKAN GRADE I PADA PASIEN YANG BERISIKO MENGALAMI LUKA TEKAN DI RSU KABUPATEN TANGERANG. Jurnal Medikes (Media Informasi Kesehatan), 5(2), 192-205.

Widodo, W., Rosa, E. M., \& Kurniasari, N. (2017). PENGARUH TINDAKAN KEPERAWATAN REDUKSI LUKA TEKAN TERHADAP PENURUNAN RISIKO LUKA TEKAN. Jurnal Ilmiah Kesehatan Keperawatan, 13(2). https://doi.org/10.26753/jikk.v13i2.214 


\section{This page is intentionally left blank}

